$J J M L L$

\title{
Delectable pleasures: Alcohol, Drinking and Subversive Masculinities in the Comedies of Etherege and Wycherley
}

\author{
Laura Martínez-García* \\ Department of English, French and German, University of Oviedo, Spain
}

Received on: 28-10-2020

Accepted on: 28-2-2021

\begin{abstract}
The year 1660 not only meant the return of the English monarchy, but it also signalled the return of parties and feasts, of drinking and eating in excess after eleven years of Puritanical abstinence. Both the tavern and the banquet halls were prominent spaces of homosocial male sociability at the time, intended for male bonding, sex talk and discussion of sexual prowess, three essential stages in the manhoodacquiring process. This paper argues that Etherege and Wycherley, two of the most prominent Restoration playwrights, not only present us with instances of banqueting and drinking in their plays, but also that their representations of drinking subvert the manhood-affirming nature of alcohol and drinking, thus questioning and subverting established gender roles.
\end{abstract}

Keywords: Gender performativity, Drinking, Alcohol, Masculinity, Sexuality, Homosocial relations.

\section{Introduction}

Food studies have seen a surge in popularity and interest in the last decade and many are the critics that recognise them as deeply significant cultural practices that can communicate profound identity issues, such as class, gender or race. Many studies have been made of drinking ballads and songs, as well as different witness accounts of banquets, both in the royal court and in taverns, during the early modern period. The comedy of manners of the Restoration has been a source of interest of literary critics and historians for many decades now and it has been acknowledged as one of the clearest examples of the deep crisis of masculinity that the cultural and epistemological shift of the late $17^{\text {th }}$ century brought about. Still, there are virtually no studies which relate both fields, which seems an oversight since the Carolean period was a moment when banqueting, merry-making and general celebration were at the centre of city life. Consequently, it seems imperative and necessary to analyse how the Restoration comedy of manners makes use of banqueting, food and drink as tools to further question established gender roles. Thus, this paper is innovative in that it brings together food studies and literary criticism to bridge the gap in between the two disciplines

The present piece of research, thus, posits that the Restoration comedy of manners, as written by George Etherege and William Wycherley, subverts and questions the traditional homosocial nature of the drinking reunion. Through the comparative study of two plays by two of the best-known playwrights of

\footnotetext{
๑ 2021 JJMLL Publishers/Yarmouk University. All Rights Reserved,

* Doi: https://doi.org/ 10.47012/jjmll.13.2.10

* Corresponding author: martinezlaura@uniovi.es
} 


\section{Martínez-García}

the 1670s, this piece of research argues that the Restoration was a period which clearly questioned and redefined gender roles. Caught between a medieval conception of the world or "deployment of alliance" (Foucault 1998, 106) and a more 'modern' social system or "deployment of sexuality” (Foucault 1998, 106), the Restoration rejects the traditional gender roles and identities proposed and spread by both systems, putting forth alternative ways of being a man or a woman which incorporate the libertine and Hobbesian philosophies. Thus, the Restoration comedy of manners, the most representative genre of the time, emerges both as a point of resistance against the dominant social systems and as a more inclusive, albeit utopian, order. The two plays which are the focus of this study, namely Etherege's The Man of Mode and Wycherley's The Country Wife, use a myriad of strategies to question the status quo and the normative identities that both the deployment of alliance and sexuality propose and they do it through the reversal of the social conventions that form the basis of the highly encoded gender roles that buttress both systems. This study focuses on the re-gendering of alcohol and drinking to support the idea that Restoration comedy, far from being a frivolous genre, is a powerful tool for social commentary.

\section{Carolean London: Between the Deployment of Alliance and Deployment of Sexuality}

Despite the fact that Wycherley's and Etherege's theatrical production was not long or especially prolific, "they wrote a combined total of only seven comedies" (Kachur 2004, 1), both authors, alongside their two best-known plays, have become paradigmatic of Carolean times and of what has been called the libertine spirit of the Restoration (Linker 2011, 78). The return of the monarchy after the 11-year Commonwealth meant a breath of fresh air for many, "a time of universal festivity and joy" (Keeble 2008 , 40) which heralded a glorious period in British history. The King's arrival meant a total departure from Cromwell's strict Puritan policies and the return of those entertainments that had been long vanished from public life: theatre, Christmas and general merry-making all made a comeback under the rule of King Charles II, known as the Merry Monarch. Charles II has been a controversial figure for centuries, alternatively vilified as lazy, indolent and a debauchee and glorified as a shrewd statesman and a political mastermind. Some historians have disputed Charles's ability and interest in matters of state (Ashley 1971;

Kenyon 1990; Molloy 1885; Ollard 2001), based on Pepys's diary entries which relate the latest gossip about the monarch. ${ }^{1}$ Others, like Antonia Fraser (2004), view King Charles not just as a successful statesman and ruler, but also as an icon of style and culture during his reign.

Opposing views notwithstanding, the Restoration of the monarchy and Charles's reign, were key points in the history of Britain and in the configuration of the epistemological truths that sustained the social fabric. As Foucault points out, the $17^{\text {th }}$ and $18^{\text {th }}$ centuries signalled a change in the discourses of truth that buttressed patriarchal power: for centuries, society had been organised into a feudal system or "deployment of alliance" (Foucault 1998, 106) which forcibly placed men and the King at the centre of life, as rulers of land and family. This system did not only predicate the superiority of men, but it also spread the view that women were but imperfect copies of men, who is the perfect first copy of God himself. This understanding was based on the teachings of Galen, the father of Roman medicine, who claimed that women were not just naturally colder, but that their sexual reproductive organs were a reversal of the male ones (Galen 1968, 57). This gave rise to the "one-sex" model which served as the 
Delectable pleasures: alcohol, drinking and subversive masculinities in the comedies of Etherege and Wycherley

basis for the social order from the second century AD to, approximately, the sixteenth century AD (Fletcher 1999, 34). This model, coupled with Biblical teachings, spread the idea that certain men (i.e. white, rich, middle-aged, married ones) were superior to women and that this superiority granted them authority over females, children, other males and elderly people, just like the monarch had authority over all of his subjects, for "a familie is a little Church, and a little common|wealth, [...] a schoole wherein the first principles and grounds of gouernment and subiection are learned" (Gouge 2005, 19). Furthermore, both the monarch's and the father's authority could and should be wielded through the spilling of blood when necessary (Foucault 1998, 147), all in the name of maintaining power and the purity of bloodlines (Foucault 1998, 147).

Towards the end of the $17^{\text {th }}$ century, the deployment of alliance lost some of its power and influence in favour of a new system, the "deployment of sexuality" (Foucault 1998, 106). It was during this time that there was a general movement of rejection of absolutist monarchies in the West, a type of feudal government that represented the most visible form of power of the deployment of alliance. This system, based on deduction, on the spilling of blood and on the threat of death as a show of power, was showing signs of decay and, while the deployment of alliance was never truly supplanted, it "lost some of its important as economic processes and political structures could no longer rely on it as an adequate instrument or sufficient support" $(1998,106)$.

The modernisation of society, the passage from the Renaissance to what has been called the Early Modern period, with its emphasis on productivity and industrialisation, was a change felt in all fields of life; in Discipline and Punish Foucault makes a study of this evolution in the punitive system, linking the changes in prisons with the evolution of the idea of subjects and individuals. The French philosopher points out in his work that the $17^{\text {th }}$ and $18^{\text {th }}$ centuries saw a call for more humane treatment of criminals in prisons: instead of inflicting cruel bodily punishment on them (the spilling of blood symbolic of the deployment of alliance), philosophers and politicians now called for the rehabilitation of criminals, through a subjugation and control of the body that not only limited movement, but which imposed strict timetables and exercising regimes, thus ensuring obedience and the reformation of conduct without the use of visible physical violence. The aim, as Foucault points out, was not to punish less, but to punish better, more effectively, to discipline bodies and create docile subjects which would be now economically productive and useful for the new industrial society $(1999,92)$.

This idea of controlling, monitoring and penetrating the body stems from the change in the nature of power: if the deployment of alliance was characterised by being a repressive power that had "the right to decide over life and death" (Foucault 1998, 135) the deployment of sexuality, at least on the surface, is based on "a power that exerts a positive influence on life, that endeavours to administer, optimize, and multiply it, subjecting it to precise controls and comprehensive regulations" (Foucault 1998, 137). This reformulation of power and its supposed preoccupation with life and its administration (seen in the passage of cruel bodily punishments in prisons or even households to the more humane 'modern' prisons and a different family model), meant that the deployment of sexuality was now interested in administering bodies as the natural locus of life: the new system penetrated the body, regulated it, 


\section{Martínez-García}

categorised it, analysed it and subjugated it, putting all its focus on sexuality and sex, as inextricably tied to the body. Still, unlike the deployment of alliance which considered sex under the scope of religion, the deployment of sexuality created the illusion of sex being a natural given, a biological trait that could thus be analysed, categorised and studied scientifically. ${ }^{2}$

Thus, after the scientific revolution of the $17^{\text {th }}$ century, the new ordering of society invoked the recent scientific discoveries as its justification for the subjugation of women, children, elderly people, and certain males. It was, in the words of Fletcher, "a new kind of patriarchy which would be founded on sexual difference rather than homology" (Fletcher 1999, 67). Although it is true that the scientific minds of the time, like Descartes, did not specifically address female inferiority (Fletcher 1999, 289), his scientific method and ideas were appropriated and used to impose a new ordering of society: whereas the deployment of alliance had been forceful and violent, the deployment of sexuality presented itself as reasonable, rational and positive. Women were no longer inferior to men, but different from them, biologically distinct and with certain natural tendencies that rendered them better suited for a certain lifestyle. Men were rational, naturally inclined to rule, strong enough to deal with the stress of public office; women, meanwhile, were naturally fragile, delicate and nurturing, biologically built to take care of children, with the home and domestic realm as their natural habitat. As Jacquie Smyth explains,

The traditional image of the Western European bourgeois male was that of a public figure. [...] A woman's sphere, in contrast, was far more limited in the traditional bourgeois society. She was instructed to remain home so she could raise her children and provide their education $(2008,28)$.

These gender notions were spread and disseminated in Britain through conduct books and manuals which attempted to control bodies outlining 'natural' masculine and feminine behaviours, while condemning unnatural gender performances. And it is precisely these books that teach children and young adults how to behave according to their sex, supporting Butler's idea that gender, rather than a biological given, is a performance, a "repeated stylization of the body, a set of repeated acts within a highly rigid regulatory frame that congeal over time to produce the appearance of substance, of a natural sort of being" (2007, 33). Gender, then, is not a biological characteristic but a cultural construction imposed on individuals' bodies which are forced to enact a series of gendered practices that render them "male" or "female", performances which ensure that gender, a cultural category, becomes "naturalised" through repetition. Thus, the conduct books of the $17^{\text {th }}$ century, with their detailed descriptions of what "manly" and "womanly" behaviour is and with their advice on how to behave according to one's "natural gender" contribute to the categorisation of certain behaviours as natural or unnatural according to one's sexual reproductive organs, they attempt to categorise and subjugate bodies to the rules of science. More importantly, these conduct books or manuals not only outlined the proper gendered behaviour for both males and females, but they also recommended certain practices and gender performances as conducive to achieving the status of "man" or "woman". For males, the manhood-acquiring process entailed a period of youthful excess (drinking, whoring, fighting), followed by marriage and control of a household, which was seen as the ultimate trial and demonstration of manhood, a path fraught with difficulties and trials (Foyster 2014; Shepard 2006). 
Delectable pleasures: alcohol, drinking and subversive masculinities in the comedies of Etherege and Wycherley

In the case of women, the general "social and ethical position [held] that chastity was the most important virtue for women, and that rationality and chastity were incompatible" (Gibson 2006, 1), an idea which reinforced the separation of genders and spheres into the dichotomies of men-public and women-private. In 1740, and at a time when the deployment of sexuality (and its gender difference) was well established as the ruling social order, Wetenhall Wilkes wrote his Letter of Genteel and Moral Advice to a Young Lady. The advice book is a good example of the conduct manuals of the time that not only praised "feminine" virtues, but which, more interestingly, censured certain practices and performances, arguing that they were "unnatural" and a betrayal of one's own biology and instincts: "Chastity is so essential and natural to your sex, that every declination from it is a proportionable receding from womanhood. An immodest woman is a kind of monster, distorted from its proper form" (Wilkes 1746, 103). This naturalisation of gendered behaviour and the accompanying labelling of any other performances of gender as aberrant and unnatural served to buttress the ideology of gender that relegated women to the home, and which subjugated them to the authority of a man.

Nevertheless, patriarchy is not a monolithic entity. In fact, no social system is based on the control of all women by all men, since power and "manhood [were] restricted to a minority of men at any one time" (Shepard 2011, 82-83). Thus, males were also instructed on the proper behaviour that would ensure the acquisition of manhood and power over others, while they were warned against certain dangerous bodily practices that went against their nature and which, consequently, would render them unfit to claim their patriarchal authority. The image of the ideal man of the deployment of sexuality was "configured around the virtues of rational self-government, thrift, moderation, strength, courage, fortitude" (Shepard 2011, 83) as opposed to "cowardice, prodigality, licentiousness, libertinism, brutishness, rusticity, dishonesty and idleness" (Shepard 2011, 83), practices and behaviours that were to be indulged in only during the formative teenage years and which were to be abandoned on one's path to patriarchal manhood.

Still, and as Shepard argues, those males who "by normative standards, failed to be patriarchs, did not necessarily fail to be men. Instead, many drew upon and developed alternative and counter-codes modes of manhood" $(2011,84)$ which not only privileged homosocial relations, but also became, despite their subversiveness, normative in the margins of mainstream society. As Foucault explains, (patriarchal) power is not merely a repressive force that seeks to destroy any counter-discourses, but rather, it is a creative force that allows for the existence of these alternative and oppositional identities and discourses; "where there is power, there is resistance" $(1998,95)$ and the Restoration (and its notions of gender) is precisely one of these spaces of resistance between the discourses of the deployment of alliance and the discourses of the deployment of sexuality.

The Carolean period is a time of in-betweeness that allowed for the creation and dissemination of alternative modes of being a man or a woman which opposed and questioned the gender roles that both the deployment of alliance and the deployment of sexuality promoted as prescriptive. In fact, the archetypical man of Restoration drama, the rake, is unable to reap the rewards of patriarchal manhood under both the deployment of alliance and the deployment of sexuality due to his libertinism, hedonism and general disregard for self-control and discipline; furthermore, the rake, with his penchant for 


\section{Martínez-García}

debauchery and in his defence of a Hobbesian existence, defies manly natural tendency to reason and measure, becoming the embodiment of the counter-discourses of gender that the Restoration preached. Female libertines, a feature of the Restoration comedy of manners, are even more transgressive in their gender performance.

The Restoration comedies of manners present audiences an alternative mode of being a man or a woman, counter-behaviours and performances of gender that involve the "deliberate inversion of patriarchal norms, by celebrating the behaviour deemed "unmanly"” (Shepard 2011, 84) and "unwomanly". They are a set of repeated actions and performances of gender which put into question the precepts of both the feudal patriarchy and the newly-founded difference-based patriarchy. In other words, their portrayals of the rake and the female libertine as (anti) heroes, reverses the teaching of conduct books by presenting 'aberrant' and 'unnatural' gender behaviours and performances as normative, desirable and rational. While the deployment of sexuality tries to control bodies and limit the pleasures associated with them in an attempt at creating docile productive subjects, Restoration comedy of manners completely gives in to these pleasures and bodily practices, allowing for individuals and their bodies to escape the control of power and its insistence on the productivity of bodies: ${ }^{3}$ in their debauchery rakes and female libertines are seen by the deployment of sexuality as unproductive members of society, bent on sensual pleasures (drinking, cuckolding, libertinism, wit and debauchery) which emerge as the gendered practices that would render one a "man" or a "woman" under the Restoration.

\section{Gendered practices: Drinking and banqueting in The Country Wife and The Man of Mode}

The Country Wife (1675) is, without a doubt, Wycherley's masterpiece and, as Maik Goth explains, “in many ways the quintessential Restoration comedy" $(2015,81)$. It premiered on January 1675 in Drury Lane (Kachur 2004, 144), becoming a success and turning Wycherley into a celebrated playwright. The comedy tells the story of Horner, one of the most notorious rakes in London, who returns from a trip to France claiming to be a eunuch after becoming sick with some sort of venereal disease on the continent. The audience soon learns that these claims are nothing but a trick Horner plays on unsuspecting husbands who would certainly allow their wives the company of such a harmless and unmanly man. Thus, the whole play revolves around Horner's liaisons with married women. The title of the play comes from the subplot, which also has Horner at its centre: Pinchwife, an old rake, returns to the city and to his old friends as a married man, after marrying Margery, an innocent and ignorant wife who will not cheat on him. Obsessed with the idea that Margery might cuckold him, he insists on locking her up and keeping her away from his former friends, threatening her and exploding in bursts of jealousy that result in her running into Horner's bed.

The Man of Mode, Etherege's best-known play, was a blockbuster when it was first staged at the Duke's Theatre in 1676 and earned the author fame and recognition as one of the most talented playwrights of his time. This archetypal Restoration comedy of manners follows the adventures of the rakish Dorimant, who is intent on getting rid of his jealous lover, Mrs Loveit, to take up an affair with her best friend Bellinda, while still trying to snatch up a rich heiress, Harriet. Meanwhile, Harriet is being forced to marry the meek Young Bellair, who is in fact in love with Emilia; Young Bellair's father, Old 
Delectable pleasures: alcohol, drinking and subversive masculinities in the comedies of Etherege and Wycherley

Bellair, is also in love with Emilia, his son's intended. The title The Man of Mode makes a reference to the foolish Sir Fopling Flutter, a frenchified man whose modishness and ridiculous manners make him the butt of all the jokes.

The last decade has seen a surge in the study of food and drink and their relation to culture: from Scholliers's general study of drinking and eating habits in medieval and pre-modern Europe (2001), to Burnett's exploration of drinking habits throughout British history (2012), researchers have been paying close attention to drinking and eating as ritualised practices that go beyond the mere consumption of food and beverages, to conclude that feasting, banqueting, or meeting of friends over a drink in public or private were highly encoded social performances which allowed participants to define their own identity and align themselves with a specific social group (Carrel 2006; Frantzen 2017; Grimm 1996; Hietala and Vahtikari 2003; Kaufman and Vlagopoulos 2019; O’Connor 2015; O'Callaghan 2007).

The clear and undeniable conclusion that one may extract from the literature on the topic of food and drink in early modern times is that alcohol became a cornerstone of the identity of the male Londonite of the $16^{\text {th }}$ and $17^{\text {th }}$ centuries: whether they were poor workers, rich lawyers or something in between, men met other men, drank (ale or wine, depending on their social class), sang bawdy songs or political ballads and engaged in deeply ritualised shows of friendship and comradery. Both Wycherley and Etherege were no different and, as part of the elite group of the Court Wits (a merry band of men who would accompany the King in all his adventures and escapades, characterised by their libertinism, wit and general charisma), their lives revolved around the consumption of wine and the associated performances of masculinity and friendship particular to their own Hobbesian understanding of the world.

Despite rejecting both the deployment of alliance and the deployment of sexuality while eschewing conventional performances of gender, the Court Wits appropriated some normative social practices and reconfigured them to inscribe their own sexual identity upon them. Drinking is one such practice: while both the deployment of alliance and the deployment of sexuality saw moderate drinking as a fundamental ritual in the manhood-acquiring process of youth (Shepard 2011,116), rowdy drunkenness was censured and viewed as a "threat to the social order", a sin which would unequivocally lead to other more serious crimes, such as fighting, blasphemy, whoring or even murder (Rabin 2005, 457). As Amussen explains, "sobriety [...] was a central component of a respectable man's life. In spite of the ubiquity of alcoholic beverages in early modern society, drunkenness was generally condemned [...] [it] implied being out of control and irresponsible [...] [and] undermined one's ability to support oneself and one's family" (1995, 225). Drunkenness, thus, robbed a male of his manhood, of his right to exert his authority over others by virtue of his natural inclination towards reason; drunkenness equalled risk and, as a manhood-debilitating practice, it was to be avoided.

The Restoration rakes, on the other hand, as representatives of an alternative mode of manhood, which clearly opposed and questioned the dictates of both the deployment of alliance and the deployment of sexuality, relished in excess of sex, food, drink and any other sensual pleasures that normative "men" were denied. The model of masculinity embodied by the Restoration rake is what Shepard calls a 'counter code', an alternative performance of gender which encouraged normative unmanly behaviour $(2011,84)$. 


\section{Martínez-García}

Thus, drink and excess are a central part of the gender identity of the Restoration rake, and the two plays studied are no exception: these libertine manifestos, both The Country Wife and The Man of Mode, can be seen as the Restoration counter-response to the conduct manuals written by priests and moralists, presenting their audiences with what they believed to be appropriate (and inappropriate) gendered behaviour.

In the case of The Country Wife, Horner (the false eunuch and uber-libertine) embodies the ideal rake-hero of the Restoration comedy of manners: his unscrupulous plan to deceive London husbands and to seduce their wives not only proves his superior intellect and wit, but also his indisputable sexual charisma and attraction. As Susan J. Owen explains, he "sets up a standard of normal male behaviour and identity" (2004, 132-33) within the play, a standard that no other male in this theatrical universe can live up to. One of the most interesting aspects of the play is Horner's relationship to his so-called friends: although Horner is seen by all of them as unmanly due to his supposed inability to perform the sexual act, his wit and general attractiveness mean that he is not ostracised or repudiated by the rest of the city wits, who inhabit a ruthless world in which males "delight in deriding one another and scoring off points off one another" (Owen 2004, 136). In such a highly competitive Hobbesian atmosphere, only the wittiest and strongest will come out victorious; Horner's supposed impotency should mean that he will be the butt of all jokes, as ritual humiliation of "friends" was part of a healthy performance of masculinity (Shepard 2006), but his mastery of deceit means that he maintains his prime position at the centre of the group, leading the drinking reunions and, more importantly, the bawdy talk that invariably accompanies the wine.

Drink in The Country Wife is a powerful symbol associated with rakish manliness, so much so that Horner's friends seem disgusted at the idea of women drinking, ${ }^{4}$ since that is a social practice they associate with manhood, rather than femininity, as, in general terms, "drink was always an occasion for male solidarity, and in Restoration England the tavern provided a primary site for male homosocial and even homoerotic activities" (Peraino 2005, 196). Meanwhile Horner, the epitome of rakish manliness in the play, does not seem to agree with this idea that drinking is "a sign of manliness and a social adhesive of male bonding" (Owen 2004, 136) and seems quite well-informed about what goes on in all-female reunions, "QUACK: But do civil persons and women of honour drink and sing bawdy songs? // HORNER: Oh, amongst friends, amongst friends" (Wycherley 2014, 155). This conversation not only reveals Horner's intimacy with the ladies, but it also serves to separate him from his friends who believe that their appropriation and subversion of drinking as a gendered performance is uniquely manly.

Such an idea is contested in act V scene iv, where Wycherley shows Horner participating in an almost-all-female banquet (Wycherley 2012, 75) (Horner's supposed impotency would mark him as effeminate) in which women truly bond over alcohol in a way which would be unthinkable in the competitive Hobbesian homosocial world of the rakes. In this scene Lady Fidget, Mrs. Dainty Fidget, and Mrs. Squeamish, a "Virtuous Gang" who apparently reject the libertine lifestyle, visit Horner's lodgings for a banquet that results in a doubly subversive scene. The first layer of subversion comes from the ladies' singing and drinking, which is an appropriation of a gendered practice at the core of the manhoodacquiring process; the three women use this practice to define their own identity and thus question the 
Delectable pleasures: alcohol, drinking and subversive masculinities in the comedies of Etherege and Wycherley

validity of the established gendered order. A second layer of subversion comes from the fact that the scene is not simply an ironic reversal of normative gendered behaviour, but a means of communicating their own understanding of womanhood: “women's drinking is not merely a symbol of their wrestling power from men. Their ability to drink really empowers them"(Owen 2004, 138). Furthermore, Wycherley's portrayal of Horner's behaviour towards the women and vice versa is such that this "parttime share" relationship emerges as the only "healthy" and "desirable" one in the whole play.

The scene opens with Lady Fidget singing a bawdy song, a typical occurrence in manly drinking reunions (Hailwood 2013; Herissone 2013, 100) and which usually served to extoll the virtues of wine and male friendship (Hailwood 2014, 113). In this case Lady Fidget's song is a complaint against a system that allows men (or at least libertine men) the freedom to take their pleasures whenever and wherever they deem fit while women are to quench their desires (both sexual and sensual) and be satisfied with their husbands as their only sexual partners ("pittance of pleasure which they only give"(Wycherley 2012, 75)), water as their only drink ("We must not rejoice//With wine"(Wycherley 2012, 75)) and the sort of quiet reunions their husbands never have ("and noise"(Wycherley 2012, 75)). Her song also rallies against husbands who prefer the company of their male friends to the company of their wives, thus privileging homosocial relations over heterosexual ones, ("In vain we must wake in a dull bed alone,//Whilst to our warm rival the bottle they're gone"(Wycherley 2012, 75)). Lady Fidget's words are a criticism against the homosocial culture of male bonding over drinks and her song is a masterful reversal of "tavern songs [which] musically inscribe what Eve Sedgwick calls “"male homosocial desire'affective social relationships among men (whether hostile or affectionate)" (Peraino 2005, 199) which buttress patriarchal power. In fact, the whole play puts forward the idea that although "the heterosexual relationships in the play have as their raison d'être an ultimate bonding between men" (Sedgwick 1985, 55) through drinking, boasting about one's sexual prowess and a general atmosphere of Hobbesian competition, this can be either an affirmation of libertine manhood (if the heterosexual relationship is consummated) or a negation of rakish manliness (if the heterosexual relationship is truncated by abandonment, cuckoldry, disinterest or impotence). ${ }^{5}$ In fact, both The Country Wife and The Man of Mode include several male characters who are unmanned by their obsession with homosocial relations and male bonding (e.g. Sparkish and Sir Fopping Flutter), a practice portrayed as emasculating.

One of the most interesting lines of Lady Fidget's song comes towards the end, when she refers to other women as "sisters" and encourages them to unite against the unfairness of their husbands' neglect of heterosexual relations in favour of homosocial ones ("Then, sisters, lay't on, And damn a good shape"(Wycherley 2012, 75)). The use of the word "sister" emphasises the difference between the homosocial world of the rakes and that of the Virtuous Gang: while the former is a highly competitive group in which men vie to outdo one another, cheating, lying and deceiving while still extolling the virtues of friendship and comradery when drinking, the latter seems to be a close-knit group of friends for whom sexual competition and jealousy are not an issue. In fact, after their song is finished and having discussed their appearance of virtue, the ladies soon discover that Horner has been pleasuring all of them at the same time, 


\section{Martínez-García}

DAINTY: Oh Wretch! did you not swear to me, 'twas for my Love, and Honour, you pass'd for that thing you do?

HORNER: So, so.

LADY FIDGET: Come, speak Ladies, this is my false Villain.

SQUEAMISH: And mine too.

DAINTY: And mine.

HORNER: Well then, you are all three my false Rogues too, and there's an end on't.

(Wycherley 2012, 78)

In the Hobbesian world of the rakes, this would be a serious issue which would require action, since as O'Callaghan explains, "the presence of women at the table led to sexual rivalry among men" (2007, 66). In this instance, Lady Fidget, Mrs Dainty Fidget and Mrs Squeamish agree that sexual jealousy should not be a problem amongst them, since it would lead to the discovery of their secret libertinism ("Well then, there's no remedy; sister sharers, let us not fall out, but have a care of our honour"(Wycherley 2012, 78)), which would put their reputations into question and which would endanger their scheme.

This scene proves that both Horner and the Virtuous Gang publicly perform specific gender roles (the unmanly eunuch and the sober and virtuous wife) that will give them the freedom to articulate and live their own alternative manhood and womanhood in private. Furthermore, it also shows that in the intimacy of their own chambers and in the presence of their allies, both the Virtuous Gang and Horner take the same side in "a gender battle, reversing normal power relations" appropriating and subrogating one by one all the manly rituals of drink and conviviality, including "men's delight in sharing common women" (Owen 2004, 139).

In The Man of Mode, Etherege also presents us with an interesting reversal of traditionally homosocial banquets and drinking reunions, when in Act IV Scene i he portrays Old Bellair, Young Bellair, Medley and Fopling meeting for a drink after having managed to get rid of the women in the play. This is a very telling detail, which emphasises the idea that "misogyny was also part of the masculine world of the tavern" or drinking reunion (Peraino 2005, 199). At first glance, this may seem a typical meeting of friends, where these men get together to talk about women, drink and boast about their sexual prowess thus taking part in the traditional performance of masculinity in a "largely homosocial environment [...] [which] served as a loci for the exchange of masculine sexual information and erotic narrative along with more general information" (Blackburn and Stras 2016, 178). Still, a closer analysis of the scene and characters reveals its subversive nature. In this instance we find a group of males drinking in "“conviviality' or the virtue of coming together in an atmosphere of familiarity to enjoy a meal. Dining was an expression of social aspirations, civility, and splendour. The banquet, a choreographed event, was a ritual of aristocratic hospitality communicating wealth and power" (Mciver 2008,8 ), and these men are participating in a public performance of rakish manliness in an attempt at buttressing their gender performance as prescriptive within this libertine social system; as Butler explains, "one does not "do" one's gender alone. One is always 'doing' with or for another" (Butler 2004, 1) and in 
Delectable pleasures: alcohol, drinking and subversive masculinities in the comedies of Etherege and Wycherley

the case of males, they needed to perform their masculinity (whether it was the prescriptive manliness of the deployment of alliance or of the deployment of sexuality or the counter-discourses of the Restoration rake) for other men. This was done through homosocial relations and ritualised practices such as drinking, which is "an important mechanism for the reproduction of early modem manhood throughout Europe [...] a theatre of social exchange in which males were required to perform" (Brown 2007, 196).

One of the men present is Sir Fopling Flutter, a youth whose flawed performance of gender makes him the butt of all jokes. He is a young man about town, a fashionable yet ridiculously affected male or fop, one of the staple characters of Restoration comedy of manners. The fop is usually "an aristocratic figure who represents false wit, exaggerated fashions, and superficial aspirations of pretentious Restoration courtiers" (Casey 1998, 207-8), a perverted and incompetent version of the rake-hero. Fops usually have a high opinion of themselves, feeling their wit, elegance and charm superior to those of all the men around; in reality, they are usually so foolish that they are incapable of understanding jokes and double entendres, ${ }^{6}$ so self-involved that they cannot believe themselves to be the subject of all jokes and, more interestingly, incapable of culminating heterosexual relations in a satisfactory manner. ${ }^{7}$ This is not to say that fops are homosexual (Casey 1998, 208), or at least that is never implied in the plays, but rather that their constant preoccupation with fashion and manners makes them effeminate (Hardy 2012, 256), as the rakes of the play themselves demonstrate, when comparing Fopling's behaviour to that of a woman,

MEDLEY: He was Yesterday at the Play, with a pair of Gloves Up to his Elbows, and a Periwig more exactly Curl'd Then a Ladies head newly dress'd for a Ball.

BELLAIR: What a pretty lisp he has!

DORIMANT: Ho that he affects in imitation of the people of Quality of France.

MEDLEY: His head stands for the most part on one side, And his looks are more languishing than A Ladys when she loll's at stretch in her Coach, or leans her head carelessly against the Side of a Box i'the Playhouse. (Etherege 2012, 98)

In the banquet scene, and following the orders of the Old Bellair, Sir Fopling starts a song in which he praises the libertine lifestyle of drinking, late nights and sexual affairs. These types of songs, called tavern ballads, were extremely popular and common in early modern times, as they served as conduits for homosocial bonding and conviviality. While most ballads portrayed love and alcohol as complete opposites, with the latter being either an antidote to the poison of the former, a substitute for it or the only way to forget the pains it caused (Martin 2001, 109), Fopling's song joins them together and paints them as equal sources of happiness, "The pleasures of love and the joys of good wine//To perfect our happiness wisely we join" (Etherege 2012, 142) a line which is clearly ironic since Sir Fopling's amorous adventures are few and more often than not, disastrous. For instance, In Act III scene iii Sir Fopling, followed by his entourage of six footmen and a page, courts Lady Loveit. The scene shows Fopling as unmanly, since his wooing of the lady is completely disastrous: rather than flirt with her, he is more worried about pointing out all the defects on the clothes and behaviour of a group of young men standing next to them, concluding that his own attire and that of his entourage is far superior (Etherege 2012, 126- 


\section{Martínez-García}

29).

Although Sir Fopling's song does describe the routine of many rakes in the Restoration (drinking, flirting, attending plays, walks in the park, more drinking and flirting), ${ }^{8}$ his exaggerated displays of rakishness, his extravagant dress and his childish enthusiasm to prove himself "one of the boys' render him effeminate" (Martínez-García 2014, 273-74), as does his passion for all things French, which he lets slip into the song when he mentions drinking champagne as an everyday occurrence (Etherege 2012, 142) when, in reality, this type of drink was not just newly invented, but rare in Britain. ${ }^{9}$

If this song came from the lips of the comedy's rake, Dorimant, it would certainly be a tool to buttress his role as the dominant male in this Restoration play. But since it comes from the fop, the words become formulaic and void of real meaning, even emasculating, since they are devoid of wit, "a marker of true manliness" (Owen 2004, 134). Sir Fopling is no womaniser; his interactions with women are not aimed at sexual intercourse, but at publicly being more sparkish than any other rake. His performance of gender is flawed because it is too public and because, ultimately, he is an effeminate male who imitates the behaviour of fashionable men like Dorimant, paying compliments to women, flirting with them but never actually consummating the action. He is an unmanly male by Restoration standards, because he lacks any sexual appetite; he is unmanly in the eyes of the deployment of alliance, since he lacks any authority and he is effeminate in the eyes of the deployment of sexuality in his excessive preoccupation with outward appearance and in his affected behaviour. The fop is then the opposite of the true rake-hero, who, "unlike the men around him, is actually interested in women, rather than in the opinions of other men" (Sedgwick 1985, 55).

But it is not just the singer that is far from the rake-hero ideal: all his drinking companions are unmanly as well; Old Bellair is another one of the types of Restoration comedy, the old lecher. Taking into account that the world of most Restoration comedies is "a world of young men" (Owen 2004, 136) in which they all vie for a claim to manliness, this old debauched man whose excessive sexual appetite makes him prey on the young ladies is a perversion of the rake-hero, whose youth and charm place him at the top of the pyramid. Under the deployment of alliance and the deployment of sexuality, Old Bellair would also be seen as unmanly, due to his age and his lack of self-restraint when it comes to sexual desire; history of drama is full of examples of old lecherous men who pursue young ladies either for their bodies, fortunes or both, and Restoration comedy of manners is no exception: those qualities which make rakes desirable (wit, sexual potency, ruthlessness) render older men effeminate and ridiculous, since, as Ellis points out, sexual passion in old age was an unnatural behaviour and "the power of love (was) destructive and effeminate in the old" $(2009,71)$. Science and philosophy "portrayed (old men) as being untroubled by the hasty impulses and burning lusts of youth" (Shepard 2006, 42) and it was their continued show of "wisdom and authority, temperance and piety" (Shepard 2006, 42) that would ensure they would not be excluded from the dividends of patriarchal power on the basis of age. Thus, any old man who gave in to the power of lust or who expressed a sexual appetite, was deemed unmanly and effeminate, unnatural and excluded from positions of power.

His son, Young Bellair has all the attributes that the deployment of alliance and the deployment of sexuality categorise as manly: he is young, rich and capable of controlling his sexual impulses. Still, his 
Delectable pleasures: alcohol, drinking and subversive masculinities in the comedies of Etherege and Wycherley

hesitance and lack of self-confidence make him unmanly not just for these two social systems, but for Restoration standards. For instance, in his affair with Emilia, it is Harriet who takes the initiative and pushes him to act so as to prevent an unwanted union; he remains passive, a characteristic which was positive or natural in women (Fletcher 1999), but which emasculates him, as both the deployment of alliance and the deployment of sexuality preached that men were assertive, capable of taking action and the natural leaders of society (Fletcher 1999, 95). Furthermore, for the libertines, Young Bellair is also effeminate since he rarely takes part in their competitive performances of manhood and when he does, he can never surpass Dorimant's performance.

All the characters in the play treat him with contempt, as if he were a child who knows nothing about the world; in Act I scene i Medley and Harcourt berate Young Bellair for his absence from their reunions, since it seems the young man has spent most of his time courting Emilia, favouring heterosexual relations, neglecting homosocial libertine relations ("MEDLEY: y'ave made us miserable by the Want of your good Company” (Etherege 2012, 97)). Still, once he does meet his friends, he eagerly joins the conversation and their criticism of Sir Fopling and his ridiculous affectations; this was part of a common social practice which entailed pointing out unmanly behaviours from other males, so that one's behaviour may be perceived as manly. Unfortunately for Bellair, neither Medley nor Dorimant believe he is one of the rakes either since, although he is pleasant company and handsome, he lacks the necessary wit and intelligence that characterise rake-heroes,

MEDLEY: A very pretty Fellow this.

DORIMANT: He's Handsome, well bred, and by much the most Tolerable of all the young men that do not abound in wit.

MEDLEY: Ever well dress'd, always complaisant, and Seldom impertinent; you and he are grown Very intimate I see.

DORIMANT: It is our mutual interest to be so; it Makes the Women think the better of his Understanding, and judge more favourably of my Reputation; it makes him pass upon some for A man of very good sense, and I upon others for a Very civil person. (Etherege 2012, 99)

Dorimant's admission of his using Bellair confirms the competitive nature of male "friendship" and of the rake's Hobbesian techniques to survive in such a ruthless environment in which only those whose gender performance is successful will be able to claim manhood. Bellair, handsome, rich and young, may look like the ideal candidate to claim his masculinity, but his general meekness and lack of initiative render him unmanly in all three systems.

Medley is certainly interesting: his age, social position and general character make him a perfect candidate for manliness in all three social systems. As a young man of means belonging to a fashionable group of wits in London, he is at a point in his life when all he lacks, according to the deployment of alliance and sexuality, is a wife to rule over to be able to claim his manhood since "manhood was a stage in life which was only reached [...] when youth ended in marriage [...] The honour that a man gained 


\section{Martínez-García}

through marriage was recognised by others in his community" (Foyster 2014, 46). This young bachelor is portrayed on the verge of a momentous occasion, the passage from youth to manhood, but, like all the true rake-heroes, he rallies against marriage and commitment,

I confess I am But of an untoward constitution, apt to have Doubts and scruples, and in Love they are no less Distracting than in Religion; were I so near Marriage, I shou'd cry out by Fits as I ride In my Coach, Cuckold, Cuckold, with no less fury than The mad Fanatick does Glory in Bethlem. (Etherege 2012, 97)

While these lines would emasculate any male under the deployment of sexuality and the deployment of alliance since both privileged marriage as the ultimately manhood-granting experience, they would be typical for any Restoration rake-hero who would see marriage as a threat to his days of homosocial competition and of heterosexual promiscuity; in fact, this discourse is a gendered performance intended to buttress his Hobbesian rakish masculinity. In this case, because these words are uttered by Medley, they take on a completely different meaning and mark him as unmanly, since they confirm that his interest in women is not sexual. Dorimant's confidante spends the whole play moving between his rakish friends' chambers and Lady Fidget's lodgings, equally, at least seemingly, dividing his time between the necessary manly rituals and performances of his homosocial Hobbesian universe and the world of heterosexual relations. Medley is always welcome and warmly received in the lady's presence chambers, as seen in Act II scene i,

LADY TOWNLEY: [Medley]'s a very necessary man among us Women; He's not scandalous i'the least, perpetually Contriving to bring good Company together, And always ready to stop up a gap at Ombre, Then he knows all the little news o'the Town.

EMILIA: I love to hear him talk o' the Intrigues, Let 'em be never so dull in themselves, he'l Make 'em pleasant i’the relation. (Etherege 2012, 104)

In this brief conversation, the main reason the ladies give to desire his acquaintance is not sexual, but quite the contrary: Medley likes gossiping with these women and that passion for news and intrigue is emasculating in the eyes of the deployment of sexuality and alliance; "in the popular literature composed by me the gossip is always portrayed as female" (Foyster 2014, 59) while the male gossip is either ignored, under-represented or laughed at. Thus, most of the writings of the time plainly reject gossip as a pernicious female practice that could de-stabilize gender order and this threat was doubled when the gossip was a man. The only possible way to neutralise this danger is to label this behaviour as unmanly and effeminate.

Still, Medley is never ridiculed in the play or openly called effeminate; in fact, most of the characters (both male and female) seem to treat him with a certain amused condescendence and they seem to see no danger in his gender performance or in the intimacy with the women in the play that his passion for news invariably provokes: the ease with which Medley moves from homosocial enclaves to heterosexual ones and the fact that he is equally well received in both, reminds audiences of Horner's plan to deceive unwitting husbands and has viewers wondering whether his passion for gossip and exaggeration is proof 
Delectable pleasures: alcohol, drinking and subversive masculinities

in the comedies of Etherege and Wycherley

of his unconforming masculinity or a ploy devised to seduce women and dupe husbands. In Horner's case, his supposed emasculation grants him access to both homosocial and heterosexual circles where he was perceived as harmless; Medley is also tasked with keeping the ladies company, while he is always welcome in Dorimant's (the rake-hero) society since he is more than happy to participate in all the manly homosocial rituals of the Restoration rakes. He even engages in the already mentioned and "necessary" sex talk that features all manly reunions. In Act II scene i he tells the ladies about his playing cards with some ladies in a passage that, coming from the lips of a confirmed rake like Dorimant or Horner, would be most provocative and sexual,

MEDLEY: Indeed I had my Belly full of that Tarmagant Lady Dealer; there never was so unsatiable A Carder, an old Gleeker never lov'd to sit To't like her; I have plaid with her now at Least a dozen times, till she'as worn out all Her fine Complexion, and her Tour wou'd Keep in Curl no longer. (Etherege 2012, 104)

It seems that although Medley successfully manages to navigate homosocial and heterosexual relationships, drinking with his male friends, assisting and encouraging their affairs and entertaining and attending to the ladies, the fact that he has no acknowledged heterosexual liaisons at any point of the play puts his masculinity into question, not just under the ideas of the deployment of alliance or the deployment of sexuality, but also under the Restoration, "a social situation in which the routing of homosocial desire through women is clearly represented as compulsory” (Sedgwick 1985, 49).

Thus, this testosterone-filled drinking reunion which traditionally would work as a means to assert masculinity turns into a mockery of the performances of gender that buttress the deployment of alliance and the deployment of sexuality: with this brotherhood of unmanly males, Etherege, like Wycherley with his all-female banquet, questions the validity of the discourses of truth that encoded gendered behaviour.

\section{Conclusions: Restoration comedy of manners and the war on gendered behaviour}

Through the analysis of drinking as a gendered performance, this article has argued that both Etherege and Wycherley, following the ideas and philosophies of the libertines, subvert the traditional homosocial culture of drink in an attempt at questioning and undermining the established rules that encode appropriate gendered behaviour proposing, at the same time, a new set of gender performances and, consequently, of alternative ways of being a man or a woman. The rakes, the fops and the female libertines that populate these plays appropriate and redefine prescriptive gendered practices and habits aimed at regulating, controlling and subjugating the body, putting special emphasis on drink and its associations with prescriptive masculinity, thus subverting the established roles of "man" and "woman'. Furthermore, Restoration comedy of manners "appears as an oppositional force to oppressive forms of male power, while, in fact, suggests (sic) a viable alternative to that power" (Velissariou 1995, 126) It is a point of resistance against and between the violently repressive deployment of alliance and the subtly authoritarian deployment of sexuality and their limiting constructions of gender, a space of inbetweenness that does not merely resist prescriptive discourses of gender, but produces its own, articulating a set of Hobbesian-inspired sexual identities which privilege individual freedom and the 


\section{Martínez-García}

pursuit of pleasure. Furthermore, these libertines and their subversive discourses about the body and pleasure set the basis for the development of modern discourses on sexuality and gender which put the emphasis on the performativity of gender and the potential bodies and sexual identities have for subversion.

$$
\text { ملذات ممتعة: الكحول والشرب والذكورة الهدامة في أعمال إيثيريغ وويشرلي }
$$

لم يكن عام 1660 يعني عودة النظام الملكي فحسب، بل أشار أيضاً إلى عودة الحفلات والأعياد، والشرب والأكل المفرط بعد أحد عشر عاماً من الامتناع المتزمت. كانت كل من الحانات وقاعات الولائم مساحات بارزة للتواصل المثلي الاجتماعي للذكور في ذلك الوقت، مخصٌّة لتوطيد الترابط بين الذكور والأحاديث الجنسيّة ومناقشة البراعة الجنسيّة، وهي ثلاث مراحل أساسيّة في عملية اكتساب الرجولة. تدفع هذه المقالة بأن إيثيريغ وويشرلي، وهما من أبرز الكتاب المسرحيين خلال عصر الاسترداد، لا يعرضان أمامنا فقط حالات الولائم والثرب في مسرحياتهم، ولكن طريقة تصويرهم للشرب تهدم مفهوم إثبات الرجولة في الكحول والشرب، ويالتالي التقويض والتشكيك في الأدوار الجندرية الراسخة. الكلمات المفتاحية: الأداء الجندري، الثرب، الكحول، الذكورة، الجنسانية، العلاقات المثلية الاجتماعيّة. 
Delectable pleasures: alcohol, drinking and subversive masculinities in the comedies of Etherege and Wycherley

\section{Endnotes}

${ }^{1}$ Pepys's diary entry for May 15th, 1663 reads: "the King do mind nothing but pleasures and hates the very sight or thoughts of business; that my Lady Castlemaine rules him (Wheatley 1887, 167).

2 "Sex must not be thought of as a kind of natural given which power tries to hold in check, or as an obscure domain which knowledge tries to gradually uncover" (Foucault 1998, 105)

3 "the deployment of sexuality is linked to the economy through numerous and subtle relays, the main one of which, however, is the body-the body that produces and consumes" (Foucault 1998, 107)

4 "Wine and women, good apart, together as nauseous as sack and sugar" (Wycherley 2014, 132).

5 For a discussion of manhood in The Country Wife see Laura Martínez-García "Staging male vulnerability on the Restoration Stage: jealousy and cuckoldry in The Country Wife (1675)". El Genio Maligno, 21, pp. 1-9.

6 "BELLAIR: [Sir Fopling] thinks himself the Pattern of modern Gallantry. //DORIMANT: He is indeed the pattern of modern Foppery" (Etherege 2012, 98).

${ }^{7}$ For an in-depth discussion of fops in The Country Wife see Laura Martínez-García "Staging male vulnerability on the Restoration Stage: jealousy and cuckoldry in The Country Wife (1675)". El Genio Maligno, 21, pp. 1-9.

8 We to beauty all day//Give the sovereign sway, //And her favourite nymphs devoutly obey.//At the plays we are constantly making our court,//And when they are ended we follow the sport,//To the Mall and the Park,//Where we love till 'tis dark (Etherege 2012, 142).

9 For a detailed comparison of the fop and the rake-hero in The Man of Mode, see Laura Martínez-García Seventeenth and Eighteenth Century English Comedies as a New Kind of Drama, Edwin Mellen Press (2014).

\section{References}

Amussen, Susan Dwyer. 1995. The Part of a Christian Man”: The Cultural Politics of Manhood in Early Modern England. In Political Culture and Cultural Politics in Early Modern England: Essays Presented to David Underdown, edited by Susan D. Amussen and Mark A. Kishlansky, 213-33. Manchester: Manchester University Press.

Ashley, Maurice. 1971. Charles II, the Man and the Statesman. London: Praeger.

Blackburn, Bonnie, and Laurie Stras. 2016. Eroticism in Early Modern Music. London: Routledge.

Brown, James R. 2007. The Landscape of Drink: Inns, Taverns and Alehouses in Early Modern Southampton. History, Coventry: University of Warwick.

Burnett, Professor John. 2012. Liquid Pleasures: A Social History of Drinks in Modern Britain. London: Routledge.

Butler, Judith. 2004. Undoing Gender. London: Routledge.

Butler, Judith. 2007. Gender Trouble: Feminism and the Subversion of Identity. London: Routledge. 


\section{Martínez-García}

Carrel, Helen. 2006. 'Food, Drink and Public Order in the London Liber Albus'. Urban History 33 (2): 176-94.

Casey, Moira E. 1998. 'The Fop: “Apes and Echoes of Men”: Gentlemanly Ideals and the Restoration'. In Fools and Jesters in Literature, Art, and History: A Bio-Bibliographical Sourcebook, edited by Vicki K. Janik, 207-14. London: Greenwood Publishing Group.

Ellis, Anthony. 2009. Old Age, Masculinity, and Early Modern Drama: Comic Elders on the Italian and Shakespearean Stage. London: Ashgate Publishing, Ltd.

Etherege, George. 2012. 'The Man of Mode'. In Four Great Restoration Comedies, 87-165. New York: Dover Publications.

Fletcher, Anthony. 1999. Gender, Sex and Subordination in England, 1500-1800. New Haven: Yale University Press.

Foucault, Michel. 1998. The History of Sexuality: The Will to Knowledge: The Will to Knowledge v. 1. London: Penguin.

Foucault, Michel. 1999. Discipline and Punish: The Birth of the Prison. Translated by Alan Sheridan. London: Penguin.

Foyster, Elizabeth A. 2014. Manhood in Early Modern England: Honour, Sex and Marriage. London: Routledge.

Frantzen, Allen J. 2017. Food, Eating and Identity in Early Medieval England. Wooldbridge: Boydell \& Brewer.

Fraser, Antonia. 2004. King Charles II. London: Orion Pub Co.

Galen. 1968. Galen on the Usefulness of the Parts of the Body. Translated by Margaret Tallmadge May. Ithaca: Cornell University Press.

Gibson, Joan. 2006. The Logic of Chastity: Women, Sex, and the History of Philosophy in the Early Modern Period. Hypatia 21 (4): 1-19.

Goth, Maik. 2015. 'Double Entendre in Restoration and Early Eighteenth-Century Comedy'. In Wordplay and Metalinguistic / Metadiscursive Reflection, edited by Angelika Zirker and Esme WinterFroemel, 71-94. Berlin: De Gruyter.

Gouge, William. 2005. Of Domesticall Duties Eight Treatises. I. An Exposition of That Part of Scripture out of Which Domesticall Duties Are Raised. ... VIII. Duties of Masters. By William Gouge. http://name.umdl.umich.edu/A68107.0001.001.

Grimm, Veronika E. 1996. From Feasting to Fasting: The Evolution of a Sin: Attitudes to Food in Late Antiquity/Veronika E. Grimm. London: Routledge.

Hailwood, Mark. 2013. “Come Hear This Ditty”: Seventeenth-Century Drinking Songs and the Challenges of Hearing the Past'. The Appendix 1 (3).

Hailwood, Mark. 2014. Alehouses and Good Fellowship in Early Modern England. Woodbridge: Boydell and Brewer.

Hardy, Myronn. 2012. Catastrophic Bliss. Lanham: Rowman \& Littlefield. 
Delectable pleasures: alcohol, drinking and subversive masculinities

in the comedies of Etherege and Wycherley

Herissone, Rebecca. 2013. Musical Creativity in Restoration England. Cambridge: Cambridge University Press.

Hietala, Marjatta, and Tanja Vahtikari. 2003. The Landscape of Food: The Food Relationship of Town and Country in Modern Times. Helsinki: Finnish Literature Society.

Kachur, Barbara A. 2004. Etherege and Wycherley. London: Palgrave Macmillan.

Kaufman, Alexander L., and Penny Vlagopoulos. 2019. Food and Feast in Modern Outlaw Tales. London: Routledge.

Keeble, Neil. H. 2008. The Restoration: England in the 1660s. London: Wiley.

Kenyon, John. P. 1990. Stuart England. Hist of England Series. London: Penguin Group.

Linker, Laura. 2011. Dangerous Women, Libertine Epicures, and the Rise of Sensibility, 1670-1730. London: Ashgate Publishing, Ltd.

Martin, A. Lynn. 2001. Alcohol, Sex, and Gender in Late Medieval and Early Modern Europe. Edited by A. Lynn Martin. London: Palgrave Macmillan UK.

Martínez-García, Laura. 2014. Seventeenth and Eighteenth Century English Comedies as a New Kind of Drama: A Foucauldian Interpretation of Family Relations, Sexuality, and Resistance as Psychological Power. Lewiston: Edwin Mellen Press Ltd.

Martínez-García, Laura. 2017. 'Staging Male Vulnerability on the Restoration Stage: Jealousy and Cuckoldry in the Country Wife (1675)'. El Genio Maligno 21: 1-9.

Mciver, Katherine A. 2008. 'Banqueting at the Lord's Table in Sixteenth-Century Venice'. Gastronomica 8 (3): 8-11.

Molloy, Joseph. F. 1885. Royalty Restored: Or, London under Charles II. London: Ward \& Downey.

O'Callaghan, Michelle. 2007. The English Wits: Literature and Sociability in Early Modern England. Cambridge: Cambridge University Press.

O'Connor, Kaori. 2015. The Never-Ending Feast: The Anthropology and Archaeology of Feasting. London: Bloomsbury.

Ollard, Richard. 2001. The Image of the King: Charles I and Charles II. London: Phoenix.

Owen, Susan J. 2004. 'Behn's Dramatic Response to Restoration Politics'. In The Cambridge Companion to Aphra Behn, edited by Derek Hughes and Janet Todd, 68-82. Cambridge: Cambridge University Press.

Peraino, Judith. 2005. Listening to the Sirens: Musical Technologies of Queer Identity from Homer to Hedwig. Berkeley: University of California Press.

Rabin, Dana. 2005. 'Drunkenness and Responsibility for Crime in the Eighteenth Century'. Journal of British Studies 44 (3): 457-77. https://doi.org/10.1086/429705.

Scholliers, Peter, ed. 2001. Food, Drink and Identity: Cooking, Eating and Drinking in Europe since the Middle Ages. Oxford: Berg 3PL.

Sedgwick, Eve Kosofsky. 1985. Between Men: English Literature and Male Homosocial Desire. New York: Columbia University Press. 


\section{Martínez-García}

Shepard, Alexandra. 2006. Meanings of Manhood in Early Modern England. Oxford: Oxford University Press.

Shepard, Alexandra. 2011. Manhood, Patriarchy, and Gender in Early Modern History. In Masculinities, Childhood, Violence: Attending to Early Modern Women—and Men, edited by Amy E. Leonard and Karen L. Nelson, 77-98. Newark: University of Delaware Press.

Smyth, Jacquie. 2008. Transcending Traditional Gender Boundaries: Defining Gender Roles Through Public And Private Spheres. Elements 4 (1): 27-34.

Velissariou, Aspasia. 1995. Patriarchal Tactics of Control and Female Desire in Wycherley's The Gentleman Dancing-Master and the Country Wife. Texas Studies in Literature and Language 37 (2): 115-26.

Wheatley, Henry Benjamin. 1887. The Dedication of Books to Patron and Friend; a Chapter in Literary History. London: E. Stock.

Wilkes, Wetenhall. 1746. A Letter of Genteel and Moral Advice to a Young Lady: Being a System of Rules and Informations: Digested Into a New and Familiar Method, to Qualify the Fair Sex to Be Useful, and Happy in Every Scene of Life. C. Hitch.

Wycherley, William. 2012. The Country Wife. In Four Great Restoration Comedies, 1-86. New York: Dover Publications.

Wycherley, William. 2014. The Country Wife. London: A\&C Black. 